\title{
PENERAPAN WALKING EXERCISE PROGRAM PADA PASIEN KANKER PAYUDARA DENGAN CANCER RELATED FATIGUE DI RUANG RAFLESIA RSUD ABDOEL MOELOEK PROVINSI LAMPUNG
}

\author{
Implementation of the Walking Exercise Program for Brest Cancer patients with Cancer related \\ Fatigue in the Raflesia Room at Abdoel Moeloek Hospital, Lampung Province
}

\section{Dewi Damayanti", Merza Nopitaa, Erni Setiyowati}

\author{
Stikes Panca Bhakti Bandar Lampung \\ *Email korespondensi: dewi@pancabhakti.ac.id
}

\begin{abstract}
ABSTRAK
Pendahuluan: Penyakit kanker payudara dan pengobatan kemoterapi yang dijalani oleh pasien memberikan efek kelelahan atau Cancer Related Fatigue (CRF) yang sangat mengganggu aktivitas dan kualitas hidup pasien. Exercise atau olahraga bagi pasien kanker dibutuhkan untuk menangani masalahCancer Related Fatigue (CRF). Tujuan dari penelitian ini adalah menganalisa efek dari penerapan Walking Exercise Program (WEP) terhadap penurunan Cancer Related Fatigue (CRF). Metode dalam penelitian ini adalah penelitian terapanapllied research dengan desain penelitian One-Group Pretest-Postest Desaign, teknik pemilihan sample dalam penelitian ini adalah teknik purposive sampling. Instrument untuk menilai Cancer Related Fatigue (CRF) pada penelitian ini mengunakan Fatigue Assesment Scale (FAS). Hasil dalam penelitian ini menunjukan bahwa Walking Exercise Program (WEP) dapat menurunkan skalaCancer Related Fatigue (CRF) pada kedua responden. Berdasarkan hasil penelitian WEP dapat dijadikan sebagai salah satu manajemen kelelahan untuk masalah Cancer Related Fatigue(CRF) pada pasien kanker payudara yang menjalani kemoterapi di RSAM Provinsi Lampung. Saran: Untuk penelitian selanjutnya agar dilakukan penelitian dengan jumlah sample yang lebih banyak dan adanya kelompok kontrol dan kelompok yang diberi intervensi agar diperoleh hasil secara statistik dan lebih valid.
\end{abstract}

Kata kunci: Cancer related fatigue; Kanker payudara; Walking exercise program.

\section{ABSTRACT}

Introduction: Breast cancer and chemotherapy treatment that is carried out by the patient gives the effect of fatigue or Cancer Related Fatigue (CRF) which greatly disrupts the activity and quality of life of the patient. Exercise for cancer patients is needed to deal with the Cancer Related Fatigue (CRF) problem. The aim of this study is to analyze the effects of the application using Walking Exercise Program (WEP) on the decrease in Cancer Related Fatigue (CRF). The method in this study is applied research with One-Group Pretest-Postest Desaign research design, sample selection technique in this study is purposive sampling technique. Instrument to assess Cancer Related Fatigue (CRF) using Fatigue Assessment Scale (FAS). Results: The results in this study indicate that the Walking Exercise Program (WEP) can reduce the scale of Cancer Related Fatigue (CRF) in both respondents. Based on the results of the WEP study can be used as one of the fatigue management for Cancer Related Fatigue (CRF) problems in breast cancer patients undergoing chemotherapy in Lampung ProvinceHospital. Suggestion: For the next researcher, do the research with more number of samples and the existence of control groups and groups who were given intervention to obtain the results statistically and more valid.

Keywords: Breast cancer; Cancer related fatigue; Walking exercise program;

https://doi.org/10.33860/mnj.v1i1.281

(C) 2020 by the authors. Submitted for possible open access publication under the terms and conditions of the Creative Commons

Attribution (CC BY SA) license (https://creativecommons.org/licenses/by-sa/4.0/).

\section{PENDAHULUAN}

Kanker payudara merupakan penyakit dimana terjadi pertumbuhan tidak normal pada sel dijaringan terjadi pada wanita yang diperkirakan mencapai 1,67 juta kasus baru pada tahun 2012 (Kemenkes RI, 2013). Terapi penyembuhan kanker salah satunya kemoterapi yang memberikan berbagai efek 
samping. ${ }^{2}$ Keluhan paling sering pada pasien kanker yang sering ditemui adalah rasa lelah akibat kanker/Cancer related fatigue (CRF). ${ }^{3}$

Cancer related fatigue (CRF) adalah suatu perasaan subjektif tentang kelelahan secara fisik, emosi, dan kognitif yang berhubungan dengan penyakit kanker atau terapi kanker yang mengganggu aktivitas harian dan fungsi normal dan berlangsung lebih dari 6 bulan. ${ }^{4}$ Kelelahan terkait kanker merupakan gejala paling umum yang dialami oleh pasien yang menerima kemoterapi dan radiasi. ${ }^{5}$ Ada beberapa faktor yang memperberat timbulnya Fatigue pada pasien kanker diantaranya faktor fisiologis dan faktor psikososial. Faktor fisiologis diantaranya terapi kanker (kemoterapi, radioterapi, pembedahan), gangguan sistemik (Anemia, infeksi), gangguan tidur, dan penggunaan obat - obatan sedatife. Faktor psikososial meliputi kecemasan dan depresi. ${ }^{6}$

Sampai saat ini belum ada faktor penyebab pasti yang menjelaskan mengenai fatigue. Penyebab fatigue dikarenakan penyakit kanker yang progresif secara langsung mempengaruhi beberapa system organ dan menyebabkan perubahan neurofisiologis pada otot rangka, menimbulkan diproduksinya zat zat abnormal tertentu seperti sitokin pro inflamasi. Zat - zat tersebut menghambat metabolisme atau fungsi otot normal dan menimbulkan efek kelelahan / fatigue. ${ }^{78}$ Hipotesis lain yang menjelaskan mengenai penyebab fatigue adalah hipotesis tentang Adenosine Triphospate Hypothesis menjabarkan perasaan fatigue dan kekurangan energy disebabkan adanya kerusakan pada regenerasi ATP dan penumpukan produk sampingan metabolik (Asam Laktat) pada neuromuskuler dan otot. ATP merupakan sumber energy utama pada kontraksi otot rangka, sedangkan gangguan metabolisme pada pasien kanker dapat menurunkan kemampuan fisik mereka. Mekanisme inilah yang menghasilkan gejala kelelahan. ${ }^{9}$

Pasien kanker payudara yang menjalani kemoterapi mengalami perasaan lelah setelah menyelesaikan pengobatannya. The American College of Sports Medicine (ASCM) merekomendasikan latihan fisik ringan seperti olahraga berjalan/Walking exercise program dengan mengembangkan prinsip frekuensi, durasi, intensitas, dan aktifitas. WEP dilaksanakan selama 2 minggu dalam waktu 5 hari selama 15 menit. Sebelum responden memulai WEP dilakukan pengukuran denyut nadi dan tekanan darah untuk mengontrol keadaan klien, selanjutnya responden akan berjalan dengan intensitas ringan dimulai dari pemanasan selama 3 menit, inti 10 menit, dan pendinginan selama 2 menit. Pada tahap awal sebelum intervensi dilakukan, responden diberikan instrument Fatigue Assesment Scale (FAS) untuk mengukur skore fatigue sebelum (pretest) pada responden, dan setelah intervensi diberikan, dilakukan pengukuran Fatigue Assesment Scale (FAS) untuk mengukur skore fatigue setelah (posttest) intervensi.

Fatigue Assesment Scale (FAS) merupakan alat yang digunakan untuk mengukur tingkat kelemahan pasien kanker payudara yang terdiri dari 10 pertanyaan yang diinterprestasikan dengan skore : tidak pernah (1), kadang - kadang (2), dirasakan secara teratur (3), sering dialami (4), selalu dialami (5). Skore total yang diperoleh berkisar antara $10-$ 50. Dimana nilai skore $<22$ tingkat kelelahan ringan, skore $22-34$ tingkat kelelahan sedang, dan skore $\geq$ 35 tingkat kelelahan ekstrim. Selain penggunaan instrument FAS, lembar persetujuan (infont consent), informasi umum dan data demografi yang dikumpulkan dari responden adalah usia, pendidikan, pekerjaan, stadium kanker, riwayat pola kebiasaan olahraga beserta durasinya, serta status pengobatan kanker yang dijalani. ${ }^{10}$

\section{METODE PENELITIAN}

Desain penelitian yang digunakan dalam penelitian ini adalah One-Group Pretest-Postest Desaign. Populasi pada penelitian ini adalah pasien kanker payudara yang menjalani pengobatan kemoterapi di ruang Raflesia RSAM Bandar Lampung pada bulan Mei 2018. Teknik sampling yang digunakan adalah purposive sampling dan diperoleh sample sebanyak dua orang responden yang memenuhi kriteria inklusi.

Metode pengambilan data dilakukan melalui observasi dan kuesioner. Kuesioner yang digunakan untuk mengukur CRF pada penelitian ini adalah Fatigue Assesment Scale (FAS). FAS terdiri dari 10 pertanyaan yang menggambarkan kelelahan klien. Intervensi ini dilakukan dengan melakukan pengukuran denyut nadi dan TD terlebih dahulu, lalu dilanjutkan dengan berjalan santai selama 15 menit dalam waktu 5 hari dalam waktu 2 minggu. Pengukuran pretest dan postest skore Fatigue Assesment Scale (FAS) dilakukan setiap hari selama intervensi diberikan. 
Penelitian ini dilakukan di RSAM Bandar Lampung di ruang Raflesia pada bulan Mei sampai dengan Juni 2018. Data yang terkumpul dianalisis dengan cara membandingkan antara hasil penelitian terdahulu, fakta dilapangan dengan teori yang ada, serta menganalisa untuk mengetahui adanya perbedaan antara skore fatigue pada responden sebelum dan sesudah diberikan WEP dan menilai apakah ada pengaruh pemberian WEP terhadap perubahan skore CRF.

\section{HASIL PENELITIAN}

Distribusi data demografi responden dalam penelitian dilihat dari segi usia berada pada rerata usia 55 tahun. Dari segi pendidikan kedua responden berada pada pendidikan yang sama yaitu SD, kedua responden menderita jenis kanker Invasif ductal carcinoma mammae grade III. Dari segi pekerjaan responden pertama bekerja sebagai pedagang, dan responden kedua sebagai ibu rumah tangga. Sedangkan dari segi rutinitas olahraga dan aktivitas, responden pertama lebih aktif dalam dalam melakukan olahraga ringan setiap pagi dan sore hari, sedangkan responden kedua membatasi aktivitasnya.

Tabel 1. Identitas dan Riwayat Penyakit

\begin{tabular}{|c|c|c|}
\hline & Klien 1 & Klien 2 \\
\hline Nama & Ny.N & Ny.S \\
\hline Umur & 50 tahun & 58 tahun \\
\hline $\begin{array}{l}\text { Pendidikan } \\
\text { terakhir }\end{array}$ & SD & SD \\
\hline Agama & Islam & Islam \\
\hline Pekerjaan & Pedagang & Petani \\
\hline Alamat & $\begin{array}{l}\text { J1. Ratulangi gg. } \\
\text { Satria II No. } 30\end{array}$ & Candimas, Natar \\
\hline \multirow{16}{*}{$\begin{array}{l}\text { Keadaan } \\
\text { umum }\end{array}$} & Klien datang ke & Klien datang ke \\
\hline & Rumah Sakit & Rumah Sakit \\
\hline & Moeloek & Moeloek \\
\hline & diantar & diantar \\
\hline & keluarganya pada & keluarganya pada \\
\hline & tanggal 22 Mei & tanggal 23 Mei \\
\hline & $2018 \quad$ untuk & 2018 untuk \\
\hline & melakukan & melakukan \\
\hline & $\begin{array}{l}\text { pengobatan } \\
\text { laniutan }\end{array}$ & $\begin{array}{l}\text { pengobatan } \\
\text { kemoterapin }\end{array}$ \\
\hline & kemoterapi & Jenis kanker Ny. S \\
\hline & diterimanya, jenis & Invasif \\
\hline & Ny. $\quad \mathrm{N}$ & ductal carcinoma \\
\hline & Invasif ductal & mammae grade III. \\
\hline & carcinoma & Klien mendapat 6 \\
\hline & mammae grade III. & kali siklus \\
\hline & $\begin{array}{l}\text { klien sudah } \\
\text { menjalani }\end{array}$ & $\begin{array}{l}\text { kemoterapi } \\
\text { neoadjuvant, dan }\end{array}$ \\
\hline
\end{tabular}

\begin{tabular}{|c|c|c|}
\hline & Klien 1 & Klien 2 \\
\hline & kemoterapi selama & tambahan \\
\hline & 8 siklus, 6 siklus & siklus kemoterapi \\
\hline & kemoterapi klien & pasca operasi, klien \\
\hline & adalah kemoterapi & memgatakan ini \\
\hline & neoadjuvan untuk & merupakan siklus \\
\hline & mengecilkan & kemoterapi \\
\hline & ukuran tumor, 2 & pertama setelah \\
\hline & siklus kemoterapi & operasinya, jenis \\
\hline & tambahan diberikan & obat \\
\hline & untuk melanjutkan & diperoleh \\
\hline & pengobatan pasca & adalah \\
\hline & op, sekarang klien & Cyclophosphamide, \\
\hline & menjalani & Doxorubicin, dan \\
\hline & pengobatan & 5FU, letak kanker \\
\hline & kemoterapi & payudara yang \\
\hline & terakhirnya, Ny. $\mathrm{N}$ & dialami \\
\hline & memperoleh jenis & disebelah \\
\hline & obat kemoterapi & Keadaan \\
\hline & berupa & umum \\
\hline & Cyclophosphamide, & tampak \\
\hline & Doxorubicin, dan & Pemerikasaan fisik \\
\hline & 5FU, klien tampak & TTV: \\
\hline & keadaan & Kesadaran: \\
\hline & umum klien baik. & Composmentis \\
\hline & Pemeriksaan fisik & TD: $110 / 70 \mathrm{mmhg}$ \\
\hline & TTV: & HR: $70 \mathrm{x} /$ menit \\
\hline & Kesadaran: & $\mathrm{R}: 18 \mathrm{x} / \mathrm{menit}$ \\
\hline & Composmentis & $\mathrm{T}: 36^{\circ} \mathrm{C}$ \\
\hline & TD: $90 / 70 \mathrm{mmhg}$ & Hasil Laboratorium \\
\hline & $\mathrm{T}: 36,8^{\circ} \mathrm{C}$. & klien: \\
\hline & HR: $78 x / m n t$ & $\mathrm{Hb}: 11,2 \mathrm{~g} / \mathrm{Dl}$ \\
\hline & RR: $21 \mathrm{x} /$ menit & Leukosit: $6.500 / \tau \mathrm{L}$ \\
\hline & Hasil Laboratorium & Trombosit: \\
\hline & klien: & $188.000 / \tau \mathrm{L}$ \\
\hline & $\mathrm{Hb}: 13,7 \mathrm{~g} / \mathrm{Dl}$ & \\
\hline & Leukosit: $7400 / \tau \mathrm{L}$ & \\
\hline & Trombosit: & \\
\hline & $334,000 / \tau \mathrm{L}$ & \\
\hline & Klien 1 & Klien 2 \\
\hline Riwayat & Klien mengatakan & Klien mengatakan \\
\hline kesehatan & pertama & mengalami \\
\hline lalu & menderita sakit & benjolan didaerah \\
\hline & kanker sejak tahun & payudara sebelah \\
\hline & 2016, sebelum & kanan sejak tahun \\
\hline & $\begin{array}{l}\text { mendapat } \\
\text { pengobatan }\end{array}$ & $\begin{array}{l}2015 \text { dan telah } \\
\text { menjalani operasi }\end{array}$ \\
\hline & medis, klien telah & pengangkatan \\
\hline & berobat ke & tumor sebelah kiri, \\
\hline & alternatife selama 1 & namun pada tahun \\
\hline & tahun, namun klien & 2017 tumor pada \\
\hline & mengatakan tidak & payudara klien \\
\hline & mengalami & tumbuh kembali \\
\hline & perubahan justru & sebesar telur puyuh \\
\hline & makin bertambah & dan sudah di \\
\hline
\end{tabular}




\begin{tabular}{|c|c|c|}
\hline & Klien 1 & Klien 2 \\
\hline & $\begin{array}{lr}\text { parah } & \text { sakitnya, } \\
\text { klien mengatakan } & \text { selama berobat di } \\
\text { alternatif } & \text { klien } \\
\text { kehilangan } \quad \text { BB } \\
\text { yang signifikan, } \\
\text { mulai dari } 55 \\
\text { menjadi } 40 \quad \text { kg, } \\
\text { keadaan luka pada } \\
\text { payudara kirinya } \\
\text { makin bertambah } \\
\text { besar dan akhirnya } \\
\text { pecah, pada tahun } \\
\text { 2016 klien ke RS } \\
\text { untuk menjalani } \\
\text { pengobatan } \\
\text { kemoterapi } \\
\text { neoadjuvan untuk } \\
\text { mengecilkan } \\
\text { ukuran kanker } \\
\text { sebelum operasi } \\
\text { dilakukan, setelah } \\
\text { operasi klien } \\
\text { mendapatkan } \\
\text { tambahan } \\
\text { kemoterapi } \\
\text { adjuvant sebanyak }\end{array}$ & $\begin{array}{l}\text { operasi pada bulan } \\
\text { April } 2018 .\end{array}$ \\
\hline $\begin{array}{l}\text { Riwayat } \\
\text { keluarga }\end{array}$ & $\begin{array}{l}2 \text { kali siklus. } \\
\text { Klien mengatakan } \\
\text { didalam keluarga } \\
\text { tidak ada yang } \\
\text { memiliki riwayat } \\
\text { penyakit kanker }\end{array}$ & $\begin{array}{l}\text { Klien mengatakan } \\
\text { didalam keluarga } \\
\text { tidak ada yang } \\
\text { memiliki riwayat } \\
\text { penyakit kanker }\end{array}$ \\
\hline
\end{tabular}

Hasil Penerapan Walking Exercise Program pada pasien kanker payudara yang menjalani pengobatan Kemoterapi

Data tingkat kelelahan pada kedua responden sebelum diberikan penerapan Walking Exercise Program dengan melakukan pengukuran (pre-test) skala Fatigue Assessment Scale (FAS) selama lima hari dengan hasil sebagai berikut:
Tabel 2. Hasil pengukuran tingkat fatigue pada responden sebelum penerapan intervensi walking exercise program

\begin{tabular}{cccc}
\hline \multirow{2}{*}{ No } & Hari/Tanggal & \multicolumn{2}{c}{ Hasil } \\
\cline { 3 - 4 } & & $\begin{array}{c}\text { Sebelum dilakukan } \\
\text { Penerapan Walking } \\
\text { Exercise Program }\end{array}$ \\
\cline { 3 - 4 } & & Ny. N & Ny.S \\
\hline 1. & Kamis, 24 Mei 2018 & 31 & 35 \\
2. & Jumat, 25 Mei 2018 & 29 & 33 \\
3. & Sabtu, 26 Mei 2018 & 28 & 30 \\
4. & Senin, 28 Mei 2018 & 27 & 28 \\
5. & Selasa, 29 Mei 2018 & 24 & 27 \\
\hline
\end{tabular}

Dari tabel 2 dijelaskan hasil penerapan sebelum dilakukan Walking Exercise Program terhadap penurunan Cancer related fatigue pada klien kanker payudara yang menjalani pengobatan kemoterapi. Responden pada hari pertama mendapatkan nilai fatigue Ny. N (31) dan Ny. S (35), hari kedua Ny. N (29) dan Ny. S (33), hari ketiga Ny. N (28) dan Ny. S (30), hari keempat Ny. N (27) dan Ny. S (28) dan pada hari kelima skore fatigue Ny. N (24) dan Ny. S (27). Kedua responden pada hari pertama dilakukan pre-test berada dalam rentang kelelahan/fatigue ( $\mathrm{Ny}$. $\mathrm{N})$ dan kelelahan ekstrim (Ny. S), hal ini dapat dilihat dari rentang nilai pada skala Fatigue Assesment Scale (FAS) dimana skore Ny. N berada pada tingkat kelelahan $22-34$, dan Ny. S berada pada tingkat kelelahan ekstrem $\geq 35$.

Tabel 3. Hasil pengukuran tingkat fatigue pada responden setelah penerapan intervensi walking exercise program

\begin{tabular}{llcc}
\hline \multirow{2}{*}{ No } & Hari/Tanggal & \multicolumn{2}{c}{ Hasil } \\
\cline { 3 - 4 } & & $\begin{array}{c}\text { Sesudah dilakukan } \\
\text { Penerapan Walking } \\
\text { Exercise Program }\end{array}$ \\
\cline { 3 - 4 } & & Ny. N & Ny.S \\
\hline 1. & Kamis, 24 Mei 2018 & 30 & 33 \\
2. & Jumat, 25 Mei 2018 & 28 & 32 \\
3. & Sabtu, 26 Mei 2018 & 26 & 28 \\
4. & Senin, 28 Mei 2018 & 25 & 27 \\
5. & Selasa, 29 Mei 2018 & 23 & 25 \\
\hline
\end{tabular}

Dari tabel 3 dijelaskan hasil penerapan sesudah dilakukan Walking Exercise Program terhadap penurunan Cancer related fatigue pada klien kanker payudara yang menjalani pengobatan kemoterapi. 
Responden pada hari pertama mendapatkan nilai fatigue $\mathrm{Ny} . \mathrm{N}$ (30) dan Ny. S (33), hari kedua $\mathrm{Ny} . \mathrm{N}$ (28) dan Ny. S (32), hari ketiga Ny. N (26) dan Ny. S (28), hari keempat Ny. N (25) dan Ny. S (27) dan pada hari kelima skore fatigue $\mathrm{Ny}$. N (23) dan Ny. S (25). Kedua responden memperoleh skore fatigue pada rentang yang sama yaitu tingkat kelelahan (22 $34)$.

Skore fatigue yang diperoleh oleh kedua responden sebelum diberikan intervensi adalah pada skore kelelahan sedang (31) untuk responden pertama, dan skore kelelahan ekstrim (35) untuk responden kedua. Sedangkan pada hasil posttest hari kelima pada kedua responden mengalami penurunan skore fatigue kelelahan sedang (23) untuk responden pertama dan skore fatigue kelelahan sedamg (25) untuk responden kedua

Tabel 4. Hasil Pengukuran tingkat fatigue

\begin{tabular}{|c|c|c|c|c|c|}
\hline \multirow{3}{*}{ No } & \multirow{3}{*}{ Hari } & \multicolumn{4}{|c|}{ Hasil penerapan } \\
\hline & & \multicolumn{2}{|c|}{ Ny. N } & \multicolumn{2}{|c|}{ Ny. S } \\
\hline & & Pre & Post & Pre & Post \\
\hline 1. & Pertama & 31 & 30 & 35 & 33 \\
\hline 2. & Kedua & 29 & 28 & 33 & 32 \\
\hline 3. & Ketiga & 28 & 26 & 30 & 28 \\
\hline 4. & Keempat & 27 & 25 & 28 & 27 \\
\hline 5. & Kelima & 24 & 23 & 27 & 25 \\
\hline
\end{tabular}

Dari tabel 4 dijelaskan bahwa terdapat perubahan nilai skala Fatigue Assessment Scale (FAS) pada kedua responden, pada hari pertama, Ny. N mengalami penurunan nilai fatigue dari 31 ke 30 , artinya terjadi penurunan nilai sejumlah 1 point. Hari kedua $\mathrm{Ny}$. $\mathrm{N}$ mengalami penurunan nilai fatigue dari 29 ke 28, terjadi penurunan nilai fatigue sejumlah 2 point. Pada hari ketiga $\mathrm{Ny}$. $\mathrm{N}$ mengalami penurunan skala fatigue dari nilai 28 ke 26 , terjadi penurunan nilai fatigue sejumlah 2 point, pada hari keempat skala fatigue Ny. $\mathrm{N}$ turun dari nilai 27 ke 25, terjadi penurunan skala fatigue sejumlah 2 point, pada hari kelima skala fatigue $\mathrm{Ny}$. $\mathrm{N}$ turun dari nilai 24 ke 23, terjadi penurunan skala fatigue sejumlah 1 point. Sedangkan Ny. S pada hari pertama turun dari $35 \mathrm{ke}$ 33, selisih 2 point. Hari kedua turun dari 33 ke 32, selisih 1 point. Hari ke tiga turun dari 30 ke 28, selisih 2 point. Hari ke empat turun dari 28 ke 27, selisih 1 point. Hari kelima turun dari 27 ke 25, selisih 3 point.

\section{PEMBAHASAN}

Asuhan keperawatan memfokuskan pada Hasil penelitian dalam pretest menunjukan bahwa tingkat CRF pada kedua responden berada pada rentang kelelahan sedang (responden 1) dan kelelahan ekstrim (responden 2) berdasarkan kategori FAS. Menurut Yeo et all, (2012) menjelaskan bahwa dari berbagai efek pengobatan yang dirasakan klien, banyak pasien kanker lebih terganggu akibat timbulnya fatigue dari pada nyeri itu sendiri. ${ }^{11}$ Potter dan Perry (2010) juga menjelaskan keluhan paling sering ditemui adalah rasa lelah akibat kanker/cancer related fatigue (CRF).

Pada saat dilakukan wawancara dan observasi pada kedua responden mengeluh merasakan lelah setelah menjalani pengobatan kemoterapi, dan akan lebih banyak beristirahat. Cancer Related Fatigue (CRF) adalah sensasi subjektif yang secara umum dikenal sebagai perasaan lelah yang tidak proposional. Fatigue didefinisikan sebagai keletihan terus menerus dan penurunan kapasitas untuk kerja fisik dan mental pada tingkat yang lazim.

Fatigue terkait kanker adalah salah satu gejala yang paling umum yang dialami oleh pasien yang menerima kemoterapi dan terapi radiasi. ${ }^{5}$ Penyataan Borneman ini sesuai dengan hasil pre-test pada kedua responden yang mengalami fatigue yang berada pada tingkat kelelahan sedang dan kelelahan ekstrim. Beberapa faktor mempengaruhi tingkat fatigue yang berbeda - beda pada tiap responden diantaranya faktor fisiologis seperti penyakit kanker itu sendiri, pengobatan kanker, nutrisi yang buruk (American cancer society, fatigue in people with cancer), pendidikan, kualitas tidur, nutrisi, pekerjaan, riwayat pola kebiasaan beserta durasinya, aktivitas seseorang serta kebiasaan exercise seseorang, serta faktor psikologis yang terdiri dari kecemasan, depresi, dan dukungan keluarga. ${ }^{11}$

Pada saat melakukan wawancara pada kedua responden, didapatkan hasil bahwa dalam perjalanan penyakit yang diderita oleh kedua responden memiliki pengalaman emosional yang berbeda. Responden pertama mengatakan selama hampir dua tahun menderita kanker sudah hampir putus asa dikarenakan pengobatan yang dijalaninya dan merasa tidak ada harapan untuk sembuh, responden kedua mengalami stress selama menjalani pengobatan. Nugroho, 2016 menjelaskan bahwa stress emosional yang dialami oleh seseorang dengan kanker payudara akan sangat berpengaruh pada perkembangan fatigue 
pada pasien kanker payudara. Hal inilah yang mempengaruhi skore fatigue pada kedua responden.

Tingkat fatigue yang dialami kedua responden berhubungan dengan frekuensi kemoterapi yang dijalani. Kedua responden telah menyelesaikan 6 kali siklus kemoterapi neoadjuvant, responden pertama mendapat tambahan 2 kali kemoterapi adjuvant, sedangkan responden kedua mendapat 1 kali tambahan kemoterapi adjuvant. Nagla (2010) menjelaskan bahwa frekuensi pemberian kemoterapi dapat menimbulkan beberapa efek yang dapat memperburuk status fungsional pasien. ${ }^{12}$ Kematian sel terjadi pada saat sel terpapar dengan obat kemoterapi. Seringkali suatu sel harus melalui beberapa tahap pembelahan sebelum kemudian kemudian akhirnya mati. Oleh karena hanya sebagian sel yang mati akibat obat yang diberikan pada frekuensi tertentu, dosis kemoterapi berulang harus terus diberikan untuk mengurangi jumlah sel kanker. Pemberian frekuensi kemoterapi yang berulang pada klien menimbulkan berbagai perubahan fungsi fisik dan psikologis pasien, salah satu efek klinis yang ditimbulkan adalah fatigue. ${ }^{13}$ Berbagai efek yang ditimbulkan pada saat pemberian kemoterapi dapat menurunkan aktivitas sehari - hari pasien kanker payudara dan menyebabkan mereka hanya berbaring diatas tempat tidur dan tidak memenuhi kebutuhan mereka dalam beraktivitas.

Kedua responden mengalami penurunan nafsu makan setelah menjalani kemoterapi, hal ini menyebabkan keduanya tidak melakukan aktivitas berlebih. Menurut Ream, Richarson, Dann (2008) menjelaskan kelelahan terjadi karena kebutuhan nutrisi kurang sehingga munculnya rasa lelah dan menurunnya semangat untuk melakukan aktivitas, kelelahan dapat muncul beberapa hari setelah pengobatan. Kelelahan dapat terjadi akibat kebutuhan nutrisi yang kurang akibat penurunan nafsu makan. Efek kemoterapi menyebabkan adanya pelepasan sitokin seperti Tumor Nekrosis Faktor (TNF) dan interleukin yang menyebabkan hipotalamus bereaksi dengan menurunkan rasa lapar mengakibatkan pasien kemoterapi mengalami penurunan nafsu makan, sehingga kebutuhan energy dalam tubuh tidak tercukupi. Hal tersebut menyebabkan kedua klien mudah lelah karena kekurangan asupan nutrisi. ${ }^{14}$

Nutrisi yang kurang pada klien yang menjalani pengobatan kemoterapi, terutama diakibatkan penurunan nafsu makan dapat mempengaruhi tingkat kelelahan seseorang. Ariana (2009) didapatkan hasil bahwa nutrisi berpengaruh secara signifikan terhadap perasaan fatigue yang dialami responden. Kedua responden penelitian sama sama mendapat suplai vitamin secara berkala sesuai dengan resep dokter, namun peneliti tidak membahas dan meneliti lebih lanjut mengenai dampak nutrisi pada nilai fatigue seseorang. ${ }^{15}$

Berdasarkan hasil penelitian didapatkan bahwa responden pertama mengalami gangguan pada kualitas tidurnya selama dilakukan intervensi, responden pertama mengatakan sulit tidur pada malam hari dan bangun dengan perasaan lelah. Sedangkan responden kedua mengatakan bahwa kualitas tidurnya selama 5 hari diberikan intervensi baik, dapat tidur lebih awal dan bangun dengan perasaan lebih baik. Kualitas tidur yang baik akan membuat seseorang merasakan perasaan tenang dipagi hari, perasaan energik, dan lebih bersemangat untuk melakukan aktivitas. ${ }^{4}$

Faktor lain yang berpengaruh pada tingkat fatigue kedua responden adalah adanya dukungan keluarga pada kedua responden. Responden pertama memperoleh dukungan keluarga selama menjalani medikasi di RS, sedangkan responden kedua selama menjalani pengobatan kanker yang membantunya adalah anak - anaknya, suaminya telah lama meninggal, namun tidak semua anak - anaknya memiliki waktu untuk menemaninya selama menjalani pengobatan, dukungan keluarga yang diperoleh oleh pasien dengan kanker akan sangat berpengaruh pada tingkat fatigue seseorang, dukungan keluarga meliputi banyak hal diantaranya dukungan emosional, dukungan penghargaan, informasi, instrumental dan dukungan jejaring social. Anggota keluarga dapat menjadi media pendukung proses penyembuhan klien dikarenakan keperdulian pada pasien dengan kanker akan sangat berpengaruh pada proses pengobatan yang akan dijalani pasien, dan juga tingkat fatigue seseorang.

Pekerjaan dan tingkat aktivitas sehari - hari responden cukup mempengaruhi tingkat fatigue yang dialami. Responden kedua mengalami tingkatan fatigue lebih tinggi dibandingkan dengan responden pertama, responden kedua adalah seorang ibu rumah tangga yang hanya melakukan aktivitas sederhana dirumah dan lebih banyak beristirahat, sedangkan responden pertama bekerja sebagai seorang pedagang, responden pertama banyak melakukan aktivitas lain diluar rumah. Berdasarkan hasil pre- 
test sebelum diterapkan intervensi WEP, responden pertama mendapat skore fatigue 31 sedangkan responden kedua 35, hal ini sesuai dengan pendapat Stone, dan Minton (2008) yang menyebutkan bahwa inaktivitas seseorang dapat menyebabkan dekondisi terjadi, jika hal ini dibiarkan dan tidak segera melatih aktivitas secara perlahan, maka fatigue akan timbul.

Faktor yang cukup penting mempengaruhi fatigue pada kedua responden adalah kebiasaan atau rutinitas olahraga yang dilakukan kedua responden yang dapat dinilai menggunakan intervensi WEP. Data yang didapatkan dari kedua responden berupa responden pertama cukup rutin untuk melakukan exercise setelah menjalani kemoterapi, sedangkan responden kedua hanya melakukan pekerjaan rumah biasa seperti menyapu, dan memasak, dan lebih banyak beristirahat.

Tingkat nutrisi yang diterima oleh kedua responden berbeda, responden pertama mengatakan frekuansi makan setelah kemoterapi tidak banyak, sedangkan responden kedua walaupun mengalami masalah mual dan muntah sehari setelah kemoterapi, beberapa hari selama intervensi dilakukan mengalami peningkatan nafsu makan. Beberapa faktor diatas cukup berpengaruh terhadap perbedaan skore akhir pada penerapan intervensi kedua responden.

Latihan berjalan secara teratur dapat membantu mengurangi efek pengobatan seperti kelelahan. Dapat pula memperbaiki suasana hati dan perasaan percaya diri. Latihan berjalan secara rutin dapat meningkatkan konsentrasi, kreativitas dan kesehatan mental. Hal ini dikarenakan berolahraga dapat meningkatkan jumlah oksigen dalam darah dan mempercepat aliran darah menuju otak. Riset juga membuktikan bahwa jalan kaki secara teratur dapat membentu mengurangi penurunan mental pada wanita diatas 65 tahun. Latihan berjalan yang dilakukan secara rutin dapat mengurangi stress, kegelisahan dan mengendalikan amarah. Olahraga ringan seperti latihan berjalan dapat memberikan manfaat menaikan daya tahan tubuh, aktivitas olahraga ringan dapat meningkatkan hormone hormone baik dalam otak seperti adrenalin, serotonin, dopamine, dan endorphin. ${ }^{10}$

WEP dapat meningkatkan oxygen cascade (aliran oksigen) dan metabolisme sehingga terjadi perubahan pada tingkat fatigue yang dialami responden. Exercise seperti berjalan dapat meningkatkan peak oxygen consumption hingga 3-4
$\mathrm{mL} / \mathrm{kg} / \mathrm{menit}$, selain itu exercise juga dapat memaksimalkan morfologi jantung termasuk peningkatan massa dan volume ventrikel serta peningkatan pengisian dan pengosongan diastolic yang kemudian akan meningkatkan cardiac output. ${ }^{11}$ Exercise juga meningkatkan volume darah yaitu peningkatan awal volume plasma yang diikuti peningkatan massa sel darah merah sehingga berkonsentrasi meningkatnya konsentrasi hemoglobin. Peningkatan hemoglobin dan cardiac output turut serta dalam peningkatan aliran oksigen pada seluruh tubuh. ${ }^{16}$

Exercise dikenal sebagai intervensi landasan untuk melakukan control metabolik. Otot gerak adalah jaringan utama tubuh yang bertanggung jawab terhadap insulin-stimulated glucose uptake dan oksidasi lemak serta penggunaan $80 \%$ glukosa akibat kondisi stimulasi insulin. Exercise dapat meningkatkan glucose uptake hingga 20 - 100 kali pada otot melalui mekanisme insulin-independent sehingga meningkatkan metabolisme. ${ }^{16}$ Dari berbagai proses tersebut yaitu meningkatnya hemoglobin dan cardiac output, meningkatnya aliran oksigen serta peningkatan metabolism dapat membantu menurunkan tingkat fatigue yang sedang dialami responden.

Setelah pemberian WEP pada kedua responden terjadi penurun skala fatigue pada kedua pasien kanker payudara yang menjalani pengobatan kemoterapi sehingga memperingan perasaan fatigue yang dialami. Berdasarkan hasil pengukuran tingkat kelelahan klien menggunakan Fatigue Assesment Scale diperoleh bahwa skore responden pertama turun sejumlah 8 point sedangkan responden kedua turun sejumlah 10 point. Responden pertama mengalami penurunan skore fatigue saat dilakukan pre-test dan post-test yang turun secara bermakna dari jumlah skore 31 menjadi 23, sedangkan pada responden kedua penurunan nilai pretest-postest turun secara bermakna dari jumlah skore 35 menjadi 25. Hal ini dapat dijadikan dasar dalam pelaksaan WEP sebagai salah satu terapi dalam mengatasi CRF pada pasien kanker payudara yang sedang menjalani kemoterapi.

Terapi yang dijalani kedua responden dilakukan selama 5 hari dalam waktu dua minggu dengan berjalan santai selama 15 menit diikuti dengan adanya pemanasan, inti dan pendinginan, hal ini membuktikan bahwa WEP memberikan pengaruh terhadap penurunan CRF. Berdasarkan data diatas 
dapat disimpulkan bahwa terjadi perubahan nilai skala CRF sebelum dan sesudah penerapan intervensi WEP pada kedua responden. Berjalan kaki merupakan jenis aerobic exercise yang sering dipilih dan disarankan kepada pasien kanker yang mengalami fatigue karena paling efektif, mudah dan aman (Labourey, 2007 dalam Skripsi Wahyuni, dkk 2012), dengan adanya peningkatan kualitas hidup dan kepatuhan paling tinggi dibanding olahraga lain seperti berenang/swimming dan bersepeda/cycling serta dapat meningkatkan kapasitas fisik, penurunan lemak tubuh, penurunan rasa mual, penurunan fatigue, mengurangi kecemasan dan meningkatkan kualitas hidup (Borneman, tami assessment and manajement of cancer related fatigue, 2014). Pemberian WEP sebagai intervensi untuk menurunkan CRF dapat digunakan karena lebih mudah, aman dan efektif, sehingga responden dapat mengaplikasikannya setiap hari dalam kehidupan hariannya.

\section{SIMPULAN DAN SARAN}

Simpulan pada penelitian ini adalah: 1) skore fatigue pada kedua responden sebelum diberikan intervensi WEP berada pada rentang kelelahan sedang (responden pertama) dan kelelahan ekstrim (responden kedua). 2) terjadi penurunan skore fatigue setelah diberikan intervensi responden pertama turun sebanyak 8 point, sedangkan responden kedua turun sebanyak 10 point. 3) setelah diberikan intervensi WEP dapat dianalisa bahwa terdapat pengaruh pemberian intervensi WEP terhadap perubahan CRF pada kedua responden. Bagi pasien yang sedang menjalani pengobatan kemoterapi dapat menggunakan WEP sebagai salah satu intervensi untuk menurunkan kelelahan yang dirasakan.

\section{DAFTAR PUSTAKA}

1. Kartika E. Bahaya kanker payudara dan kanker serviks. Bandung: Buku Bravo; 2013.

2. Smeltzer S, Bare B. Keperawatan Medikal Bedah. 8th ed. Jakarta: EGC; 2013.

3. Potter PA, Perry AG. Fundamental Of Nursing: Consept, Proses and Practice. 7th ed. Jakarta: EGC; 2010.
4. Nugroho S. Pengaruh Intervensi Teknik Relaksasi Lima Jari Terhadap Fatigue Klien Ca Mammae Di Rs Tugurejo Semarang. Universitas Diponegoro; 2016.

5. Borneman T. Assesment and Manajement of Cancer Related Fatigue. J Hosp Palliat Nurs. 2013;2(15):77-86.

6. American Cancer Society. Fatigue in People With Cancer. 2014.

7. Stasi R, Abriani L, Beccaglia P, Terzoli E, Amadori S. Cancer-Related Fatigue: Evolving Concepts in Evaluation and Treatment. Cancer. 2003;98(9):1786-801.

8. Dahlia D, Karim D, Damanik SRH. Gambaran Fatigue Pada Pasien Kanker Post Kemoterapi. J Ners Indones. 2019;9(2):80.

9. Ryan JL, Carroll JK, Ryan EP, Mustian KM, Fiscella K, Morrow GR. Mechanisms of Cancer-Related Fatigue. Oncologist. 2007;12(S1):22-34. 10. Aghili M, Farhan F, Rade M. A pilot study of the effects of programmed aerobic exercise on the severity of fatigue in cancer patients during external radiotherapy. Eur J Oncol Nurs. 2007;11:17982.

11. Wahyuni S.I, Sudiana I K MH 2018. Walking Exercise Programme ( WEP) Menurunkan Cancer Related Fatigue ( CRF ). Crit Med Surg Nurs J. 2019;1(1):28-37.

12. Ozkan S, Ogce F. Importance of social support for functional status in breast cancer patients. Asian Pacific J Cancer Prev. 2008;9(4):601-4.

13. Yeung SCJ, Escalante CP, Gagel RF. Medical Care of Cancer Patients. USA. People's Medical Publishing House; 2009.

14. Ream E, Richardson A, Alexander-Dann C. Supportive intervention for fatigue in patients undergoing chemotherapy: A randomized controlled trial. J Pain Symptom Manage. 2006;31(2):148-61.

15. Ariani D. Tinjauan faktor yang berpengaruh terhadap kelelahan pengemudi bus. J Ilmu Kesehat. 2009;11:149-72.

16. Jones W. Exercise Intolerance in cancer and the role of exercise therapy to reverse dysfunction. Lancet Oncol. 2009;10:598-605. 